\title{
FROM AQUINA'S CIUITAS PERFECTA TO QUIDORT'S PERFECTA MULTITUDO. A 'SLIGHT' SHIFT IN MEANING.
}

\author{
De la civitas perfecta de Tomás de Aquino a la perfecta multitudo \\ de Juan Quidort de París. Un 'pequeño' cambio de sentido.
}

\author{
José Maria Silva Rosa \\ University of Beira Interior, Covilhã (Portugal)
}

\begin{abstract}
According to Arendt and Habermas, the reinterpretation of Aristotle made by Thomas Aquinas, identifying politicus and socialis, has weakened the nature of classical Aristotelian politics by introducing in the polis (now regnum / monarchy) relations and private interests that the Greeks had reserved for domestic space (oikos). Moreover, being the concept of societas in this context naturally Christian, the purpose of society is no longer self-sufficiency and acquisition of natural virtue, which allow us to live together in order to the good life, but requires supernatural virtue given by God in order to achieve the true supreme good. Therefore, the possibility of happiness (eudaimonia) now refers to eschatology (communio sanctorum), reason because kings are to be subject to priests, especially the pope, Christ's representative, whose role is to take care of the highest aim of our existence (visio et fruitio Dei). However, the application of a pyramidal and hierarchical scheme of spiritual power over the temporal realm is subverted by Juan Quidort of Paris, introducing a «small» shift: the kingdom understood as perfecta multitudo. In this perfect multitude an upward causality is the basis for distinction and non-subordination of the temporal power by the spiritual; at the same time freedom of individuals to choose their leaders is essential. This view undermines the dynastic transmission's model of power in a kingdom (from father to son) as well as, at the ecclesial level, points to superiority of the General Council in relation to the pope.
\end{abstract}

Key-Words: Thomas Aquinas, Jean Quidort of Paris, politics, society, perfect community, hermeneutics.

\section{RESUMEN}

Según Arendt y Habermas, la reinterpretación de Aristóteles hecha por Tomás de Aquino, al identificar politicus y socialis, ha debilitado la naturaleza de la política aristotélica clásica mediante la introducción, en lo que era la pólis (ahora regnum / monarquía), de relaciones y intereses privados que los griegos habían reservado para el espacio doméstico del oikos. Por otra parte, como su concepción de societas era naturalmente cristiana, el fin de esta sociedad ya no consistía tan sólo en la autosuficiencia y en la adquisición de la virtud natural, que nos permitiría vivir juntos en orden a la vida buena, pero requería una virtud sobrenatural dada por Dios con el fin de lograr el auténtico bien supremo. Por lo tanto, la posibilidad de la felicidad (eudaimonía) se remite ahora para la escatología (communio sanctorum), razón por la cual los reyes han de estar sujetos a los sacerdotes, especialmente al papa, representante de Cristo, cuya función es cuidar del último y superior fin de la existencia (visio et fruitio Dei). Todavía, Juan Quidort de París viene a alterar esta aplicación del diseño piramidal y jerárquico del poder espiritual al ámbito temporal a través de una «pequeña» inflexión en la idea de reino como perfecta multitudo. En esta es esencial la causalidad ascendente como fundamento para la distinción y no subordinación de lo poder temporal frente a lo espiritual, y la libertad de los sujetos para elegir a sus gobernantes. Esto pone en causa no sólo el creciente modelo dinástico de transmisión del poder temporal en un reino (de padre a hijo), como, a nivel eclesial, señalará la superioridad del Concilio General en relación con el papa.

Palabras-clave: Tomás de Aquino, Juan Quidort de Paris, política, sociedad, comunidad perfecta, hermenéutica. 
...the community is the source of all authority.

A. J. Carlyle ${ }^{1}$

\section{TEXTS AND COMMUNITIES OF INTERPRETATION. FROM POLIS TO SOCIETAS}

History often shows us an interesting hermeneutical circle: on the one hand, the emergence of new texts or the discovery of ancient texts has frequently generated new readers; on the other hand, new readers have always required and written more texts. However, is it enough to read or to write a text, (even, pray, a religious one), to create a community / Gemeinschaft?

It is a well-known fact that the reception of Aristotle's writings in the West, very especially the Nicomachean Ethics and The Politics in the universities of the thirteenth and fourteenth centuries, generated communities of interpretation and new possibilities to reconsider our life in common. Not only were these texts fervently [eagerly] studied by the scholars in universities and in religious orders, particularly the Dominicans (Albertus Magnus and Thomas Aquinas), but they also influenced new social order structures: churches, rising kingdoms, communes, friars' orders, schools, municipalities, craft guilds, «hanses», leagues, and so forth. According to J. Habermas, in his book Theorie und Praxis [1971], the reinterpretation of Aristotle by Thomas Aquinas led the transformation of classical politics into modern social philosophy. ${ }^{2}$ This is a pregnant statement with consequences for the study of Late Medieval Ages, mostly in regard to the «long fifteenth century».

Indeed, the Aristotelian conception of the political nature of man («man is, by nature, a

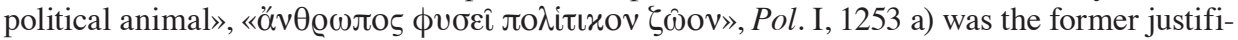
cation for the beginning and the arising of political order in history. In fact, inserted into human

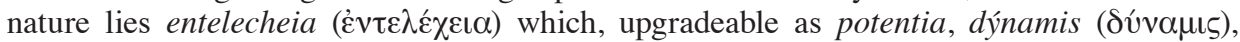
enables us to reach the perfection ( $\alpha \varrho \varepsilon \tau \eta$, excellence) of the mentioned living together. Therefore, nature ( $\phi \dot{v} \sigma \mathrm{\varsigma} \varsigma$ ) is regarded as the ground and the condition for the accomplishment of our goal as bios politikós, bios logikós, that is to say, for the achievement of our ethical-rational

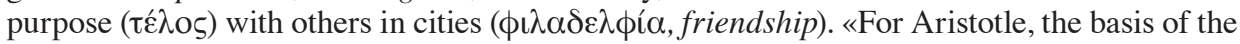
polis is the virtue of the citizen», ${ }^{3}$ not the private interests of a single group or the pursuit of their own affairs. «Aristotle is of the conviction that a polis which is truly worthy of the name and is not merely called such, must be concerned for the virtue of its citizens». ${ }^{4}$

However, some specific contents of this notion of nature ( $\phi \dot{\sigma} \varsigma \varsigma$ ) were in part surreptitiously replaced by Aquinas. As Arendt and Habermas emphasized, Aquinas understood the

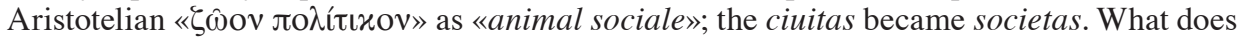
this translation mean? It means that the motivation of political life, now, is, firstly, the satisfaction of the primary necessities of life. Not political or ethical aims, but biological needs, foremost. Aquinas' version weakened classic Aristotelian politics and debilitated the latter's justification for living together. Thus, this justifies the «...translation of Aristotle's zoon poli-

1 Robert Warrand Carlyle \& Alexander James Carlyle, A history of mediaeval political theory in the West, vol. VI. Political Theory from 1300 to 1600, William Blackwood \& Sons Ltd., Edinburgh and London, 1950, p. 206.

2 Jürgen Habermas, Theory and Practice, Polity Press, Cambridge, 2007, p.48: «Aquinas transforms Aristotelian Politics into a philosophy of the social order».

3 Francisco Bertellonni, «La teoría política medieval entre la tradición clásica y la modernidade», in: Pedro Roche Arnas (ed.), El pensamiento político en la edad media, Fundación Ramón Areces, Madrid, 2010, p. 25.

4 J. Habermas, Theory and Practice, p. 47. 
tikon by animal socialis, already found in Seneca, which then became the standard translation through Thomas Aquinas: homo est naturaliter politicus, id est, socialis [sic] ("man is by nature political, that is, social"). [Summa Theologiae I, 96, 4: "homo naturaliter est animal sociale" $]^{5}$ More than any elaborate theory, this unconscious substitution of the social for the political betrays the extent to which the original Greek understanding of politics had been lost. For this, it is significant but not decisive that the word "social" is Roman in origin and has no equivalent in Greek language or thought. (...) It is only with the later concept of a societas generis humani, [i.e.] a "society of man-kind" that the term "social" begins to acquire the general meaning of a fundamental human condition». ${ }^{6}$

For Aquinas' purpose, this equivalence between politicus and socialis was very important. Actually, Christian thought had never given great emphasis to the political dimension as an ability of achieving virtue only through natural reason. Instead, it had pointed to the notion of societas perfecta, communio sanctorum, or ciuitas Dei, perfect in Paradise, lost by Adam's sin, and recovered again in the end of times by Jesus Christ's grace. In this sense, to Saint Augustine, for example, man would be originally socialis before having to become politicus, after the Adam's fall. To Aquinas, man would be created socialis and politicus at the same time. And the dream of many communities in the thirteenth and fourteenth centuries, not only the Franciscan or Dominican Orders, but also many other millenarist and xchiliastic groups (as Norman Cohn showed in his The Pursuit of Millennium), was to recover the paradisiac status via monastic life in common (living «like angels») or, at the opposite pole, through the apology for free love (the «Church of Love» of Catharism; the Fedeli d'Amore-The Faithful of Love, etc.). For them, our present condition, in statu isto, under coercive political powers, reminds us continuously, by via of contrast, of mankind's original and lost nature.

As we previously stated, this is not Aquinas' position, since for him to be politicus is not a consequence of Original Sin (peccatum originale, peccatum naturae). Nevertheless, his weakening of politics had (and has) heavy consequences: while «the polis in Aristotle presents relationships of domination that rest on reason and on the free consent of the citizen [in the greek polis, the exercise of power is a command amongst free and equal men], in medieval political theory the relationships of domination start to become despotic and be more like power relationships that take place in the oikos, and thus, to transform into economic [oiko-nomic] relationships». ${ }^{7}$ Hence Aquinas' predilection for the Monarchy, where the princeps / King rules his Kingdom like a Lord (dominus, pater familias, householder) masters his house. Politics became captive of a domestic and familiar conception of regnum, which is inherited by the sons. Thus, in Aquinas' view of societas, the polis and the oikos tend to fuse into each other in light of the same lex naturae (which will be relentlessly criticized by the nominalists like Ockham). Furthermore, in the end, Aquinas was not able (better: he didn't want) to avoid the subordination of political power to the pope's religious authority (suprema potestas papalis, potestas spiritualis); and, besides, to avoid the submission of temporal goals to spiritual purposes (caelestis beatitudo, visio Dei). Thomas Aquinas was Aristotelian, indeed, sed quantum satis.

At the same time, it would be very interesting for our topic (but we cannot develop this too far, here), to find out how the aforementioned reception of Aristotle's writings brought

5 Thomas Aquinas, De Regno sive de regimine principum ad regem Cypri, I, 2: «Naturale autem est homini ut sit animal sociale et politicum, in multitudine vivens...».

6 Hannah Arendt, A Condição Humana, Relógio d'Água, Lisboa, p.39; The human condition, Chicago University press, $2^{\text {nd }}$ ed, pp. 23-24.

7 F. Bertellonni, «La teoría política medieval...», p. 25. 
forth radical communities of readers, for instance, the so called «Averroists» in the Faculty of Arts, in Paris, like Siger of Brabant, Boethius of Dacia and, later, Marsilius of Padua (12751342). Even if they were not «Averroists» stricto sensu, they had demanded the libertas docendi et discendi against the Faculty of Theology, i.e., the same libertas interpretandi - freedom to read - that had been at the heart of the universitas congregatio magistrorum et scholarium's foundation. And we cannot forget that Ibn Rushd (Averröes), in The Decisive Treatise (Kitāb Faşl al-maqāl) had already demanded, on behalf of the Ummah, that is to say, of the Community of Believers (Ummat al-Mu'minin) the same libertas interpretandi for philosophers as well.

Ultimately, «the thomist option by the monarchy was not an option without consequences. On the contrary, the Thomist fateful shift of political philosophy into social philosophy opened the way for the substitution, in the public sphere, of the polis order to the oikos order; [that is to say], to the inrush of economy in politics, to the transformation of the public sphere into a private sphere of individual interests and [ultimately], to the substitution of the homo politicus by the homo socialis. This new order was called ordo societatis by Habermas». ${ }^{8}$ In short: the criterion of the well-founded ordo is no longer the freedom of citizens, but just tranquility and peace of order (pax tranquilitas ordinis).

\section{THE ESCHATOLOGICAL HORIZON OF THE CHRISTIAN PERFECTA COMMUNIO}

In the Christian tradition, the idea of perfecta communio has always meant or been aimed at an eschatological horizon, neither historical nor political, where the multitude of the blessed elected, live with the Lamb of God, in Heavenly Jerusalem.

In the Apocalypses / Book of Revelation $(14,1)$, St. John describes his holy vision to us: "And I saw the Lamb on the mountain of Zion, and with him a hundred and forty-four thousand, marked on their brows with his name and the name of his Father». Many scholars and exegetes have linked this eschatological vision by John with the religious experience of Israel. Every year, thousands and thousands of Jewish people ascend to Jerusalem, singing psalms (Psalms of Degrees), in order to celebrate Pessah, Rosh Hashanah, Hanukah, Yom-Kippur, Sucot, Purim, etc. Under the strong persecutions (Nabucadnezzar, $6^{\text {th }}$ century BC; and mainly under the Seleucid and the Roman Empires, $2^{\text {nd }} / 1^{\text {st }}$ centuries BC) such religious ideal suffered a plainly eschatological orientation.

Thereafter, in the New Testament, we also find such peregrinatio deeply transfigured. The author of Letter to the Hebrews $(13,14)$, for instance, tells us that «For here we have no lasting city, but we seek the city which is to come». («Non enim habemus hic manentem ciuitatem sed futuram inquirimus»). This eschatological horizon is ubiquitous in subsequent Christian thought. The perfectio vitae is always conceived after this life, out of history, in the celestial kingdom with the Invictus Christus Rex. Until then, we are simply in via as perfecti viatores, ${ }^{9}$ multitudo credentium, multitudo miserationis dei, ${ }^{10}$ etc., that is to say: multitude

8 Francisco Bertellonni, «La teoría política medieval...», p. 29; cf. J. Habermas, Theory and Practice, p. 48 .

9 Cf. Saint Augustine, De Natura et gratia, 13.

10 Saint Augustine, Enarrationes in Psalmos, 5, 8: «...in multitudine hominum perfectorum et beatorum dicit, quibus ciuitas illa constabit, quam nunc parturit et paulatim parit ecclesia. Homines autem multos regeneratos atque perfectos, recte dici multitudinem miserationis dei...». 
graced with divine mercy. After this peregrination, all of us, together, will be ciuitas sancta, says Augustine again (Enarrationes in Psalmos, De Ciuitate Dei).$^{11}$ In the $8^{\text {th }}$ century, we find in Venerable Bede, Ambrosius Autpertus, etc., the expression perfecta multitudo used to characterize the Celestial City, ${ }^{12}$ which, needless to say, has the very same number of men and angels. $^{13}$

On the contrary, as we will soon see, in John Quidort's thought, the perfecta multitudo is used to define not the heavenly kingdom, but the earthly regnum, a historical one. In-between, we find Thomas Aquinas again. Let's see, albeit briefly, his position on this topic.

In the Conclusio of the Summa Theologiae, I ${ }^{a}$ Pars, quaestio 108 (Utrum in una hierarchia sint plures ordines-about the angels' hierarchy), a.2, the notion of perfectio multitudinis is associated to the excellence of the number three, according to the archetype of the Pseudo-Denys' De Coelesti Hierarchia. Thomas Aquinas performs in this way the perfect correspondence between the three orders of medieval society -ordo iudicantium: oratores; ordo pugnantium: bellatores; ordo laborantium: laboratores $-{ }^{14}$ and the three classes of men in a perfecta ciuitas: the supremi, ut optimates; the medii, ut populus honorabilis; and the infimi, ut vilis populus. Without such ordines the multitude would not be ordered but rather disordered: "non autem esset multitudo ordinata, sed confusa, si in multitudine diversi ordines non essent». ${ }^{15}$

In the De Regno sive de regimine principum ad regem Cypri, the word perfecta occurs about one hundred times (precisely ninety-seven) but never characterizing the multitudo as such. ${ }^{16}$ In the second chapter of the first book, only the societas, the ciuitas and the communitas are qualified as perfectae..$^{17}$ On the one hand, in this text, Thomas Aquinas «remains completely within the Aristotelian tradition»: in fact, for Aristotle «even the state/polis may be founded for the sake of survival, and has permanent existence, its existence still is only for the sake of the good life». ${ }^{18}$ But for Thomas Aquinas, even if self-sufficiency is important to define the perfectio multitudinis, which is to live according to the natural virtue in order to reach the good life (bene vivere), the achievement of this goal is not possible without one last and supernatural end: the fruitio Dei, the heavenly beatitude, eternal salvation: «Yet through

11 V.g., XI, 7; XV, 2; XVII, 10; XIX (domus, ciuitas, regnum); XX, 11; XXII, 29; De Diversis Quaestionibus Octoginta Tribus, 61, 2; Enarrationes in Psalmos 44, 33; 50, 22; 61, 4-7; 86, 6; 94, 8; Sermones, 105, 9; $347,2$.

12 The Venerable Bede, Explanatio Apocalypsis, II, 14, 1 (PL 93, 173): «Ut cum de his qui in carnalis vitae constituti merito in monte Sion cum Agno videntur, tam perfecta multitudo cernatur, de caeteris Ecclesiae membris non dubitetur». Rabanus Maurus, In honorem sanctae crucis, I, 24, 44, uses the phrase as well, like Isidorus Hispalensis: congregatio vel adunatio multorum fidelium. [n.b.: referecences apud CLCLT-5 Library of Latin Texts].

13 Ambrosius Autpertus, Expositio in Apocalypsin, X, 21, 17, 60: «Quia ergo ex hominibus et Angelis constat, tanta que in ea multitudo erit hominum, quanta est et Angelorum, tam que perfecta hominum quam et Angelorum, recte mensura eiusdem ciuitatis hominis et Angeli esse perhibetur». [apud CLCLT-5 Library of Latin Texts].

14 Cf. the well-known Jacques le Goff's scheme, present in the Adalbéron de Laon's Poem: Carmen panegyricum in laudem Berengarii (Paris, 1663, apud Gallica.bnf.fr), oratores, bellatores, laboratores; Georges Duby, As Três Ordens ou o Imaginário do Feudalismo, Estampa, Lisboa, 1982.

15 Summa Theologiae, I, q.108, a.2.

16 We do not deal here with the question of whether the De Regno and the Scriptum super Sententiis II, are or not incongruous about our topic. Ignatius Theodore Eschmann, «St. Thomas Aquinas on the Two Powers», In Mediaeval Studies 20 (1958), 177, says plainly that «they are contradictory». Meanwhile, Yves-Congar, OP, has considered the end of the Scriptum super Sententiis II «enigmatic».

17 De Regno I, 2, 7: «...tanto sit perfectior multitudinis societas...; in ciuitate vero, quae est perfecta communitas...; qui perfectam communitatem regit...».

18 Jürgen Habermas, Theory and Practice, p. 47. 
virtuous living man is further ordained to a higher end, which consists in the enjoyment of God (in fruitione divina), as we have said above. Consequently, since multitude must have the same end as the individual man, it is not the ultimate end of an assembled multitude to live virtuously, but through virtuous living to attain to the possession of God (adfruitionem divinam)». ${ }^{19}$ Thus, the perfecta ciuitas is finally projected on an eschatological screen as «dream of unity», ${ }^{20}$ communio sanctorum, as we have already mentioned.

For Thomas Aquinas, the temporal and natural government, even if it has the ultimate end as goal («since the beatitude of heaven is the end of that virtuous life which we live at present»), ${ }^{21}$ it is not able, by itself, to lead the citizens there. Only Christ's grace, through its representatives, the priests, and very especially the Roman Pontiff, is able to do that. Therefore, «to him [Roman Pontiff] all the kings of the Christian People are to be subject as to our Lord Jesus Christ Himself. For those to whom pertains the care of intermediate ends should be subject to him to whom pertains the care of the ultimate end, and be directed by his rule. (...). Consequently, in the law of Christ, kings must be subject to Priests». ${ }^{22}$

But for John Quidort kings mustn't be subject to Priests in rebus temporalibus. And this slight difference in meaning between Aquinas' perfecta ciuitas and Quidort's perfecta multitudo opened new ways not only for the exercise of the political power of kings, but also for the ascendence of lay people and a new understanding of the inner life.

\section{QUIDORT ON PERFECTA MULTITUDO}

In order to properly appreciate Quidort's notion of community and perfecta multitudo we firstly need to know a bit more, not about himself — because we don't know very much about his life- but rather about his Order.

In effect, John Quidort $^{23}$ was a friar of Saint Dominic, at Saint Jacques' convent, in Paris. We know that one of the most remarkable features of the Dominican Order, from the beginning, was «the quasi-democratic nature of its structure». In fact, «every superior in the Dominican Order was elected and was responsible to the elected chapters. This was in sharp contrast to the older religious orders [of a feudal style]. Furthermore, the chapters formed the basis of

19 De Regno, I, 15: «Sed quia homo vivendo secundum virtutem ad ulteriorem finem ordinatur, qui consistit in fruitione divina, ut supra iam diximus, oportet eumdem finem esse multitudinis humanae qui est hominis unius. Non est ergo ultimus finis multitudinis congregatae vivere secundum virtutem, sed per virtuosam vitam pervenire ad fruitionem divinam».

20 Jeannine Quillet, «Pouvoir temporel et pouvoir spirituel aux XIV et XV siècle : complémentarité ou conflit?», in: Revista da Faculdade de Ciências Sociais e Humanas, (Universidade Nova de Lisboa, vol. 1, 1994$), 43$.

21 De Regno I, 16: «Quia igitur vitae, qua in praesenti bene vivimus, finis est beatitudo caelestis, ad regis officium pertinet ea ratione vitam multitudinis bonam procurare secundum quod congruit ad caelestem beatitudinem consequendam, ut scilicet ea praecipiat quae ad caelestem beatitudinem ducunt, et eorum contraria, secundum quod fuerit possibile, interdicat. » // «Therefore, since the beatitude of heaven is the end of that virtuous life which we live at present, it pertains to the king's office to promote the good life of the multitude in such a way as to make it suitable for the attainment of heavenly happiness, that is to say, he should command those things which lead to the happiness of Heaven and, as far as possible, forbid the contrary».

22 De Regno, I, 15: «...Romano pontifici, cui omnes reges populi Christiani oportet esse subditos, sicut ipsi domino Iesu Christo. (...) Sic enim ei, ad quem finis ultimi cura pertinet, subdi debent illi, ad quos pertinet cura antecedentium finium, et eius imperio dirigi. (...) unde in lege Christi reges debent sacerdotibus esse subiecti».; Thus, the pope holds the apex of both powers. Aquinas, Commentum in Lib. II Sententiarum (Paris: Vives, 1873), dist. 44, expositio textus: «...sicut in papam, qui utriusque potestatis apicem tenet...».

23 Paris, circa 1270? - † Bordeaux, 22.09.1306. 
the authority in the Order which did not filter down throughout the structure of the Order but, rather, authority moved upwards through the ranks of the Order». ${ }^{24}$ In addition, the Dominican Community was a «self-governing body (...). It was ruled by a master-general who was chosen by a general chapter composed by the representatives of each province of the Order. Each province had a corresponding organization and was directed by a provincial prior who was elected in the provincial chapter in which members from every convent in the province were represented. The individual convent was governed by a prior elected by the friars of that convent. Perhaps the most significant feature of the Order was the elective system by which those who governed the Order at every level were placed in their positions. Furthermore, their tenure in office, with the exception of the master-general, was limited to a specific number of years. After the friar had served his term in office, he returned to his former duties». ${ }^{25}$

We have to consider John Quidort's thinking in light of this communitarian environment. As we have just mentioned above, in John Quidort's kingdom (regnum) as regimen multidinis perfectae -i.e. «the rule [or the government] of a perfect multitude (regimen multitudinis perfectae), ordained to the common good (ad commune bonum ordinatum), by one man ( $a b$ uno)», ${ }^{26}$ i.e. the princeps - , the King shouldn't be submitted to the Roman pontiff. However, if the officium regis as such does not depend on the pope, does this mean that the King receives his power directly from God? By no means: «Omnis potestas a Deo, sed per populum». This is a scholastic aphorism invoked many times in this context. The elective principle present in the Dominican Order (one man one vote, we might say though, anachronously) will be subtly and inchmeal transferred to the kingdom, and even into the Church by defending the primacy of General Council.

It is not accidental but rather intentional that John Quidort begins with the multitudo, ie., with the basis of the social pyramid. Thus he gives us a clear indication of a theoretical reorientation, which was occurring during this period, according to which both political and temporal powers are justified by an ascendant causality, ${ }^{27}$ inspired by Aristotle, instead of a descending causality, according to the Pseudo-Dionysius model ${ }^{28}$ (as we see in Hugh of Saint Victor and Giles of Rome). This redirection means: the pyramid of the political, social and even ecclesial scheme in the medieval theological universe is here being re-appreciated from the bottom up, from the pars numerosa, the populus, which comes and takes a central place in the work of John Quidort. ${ }^{29}$

So, people, the whole community as perfecta multitudo, contrary to a crowd or a domestic community (domestica multitudo, communitas domus) which is not self-sufficient (sibi non sufficit) except for a short while (nisi ad modicum tempum), are able to providing their material needs during their entire life (ad totam vitam) and, for this reason, can accurately be called a city (ciuitas) or a kingdom (regnum). In order to guarantee the common good, like the

24 B. A. Brill, The Situation of Dominican..., p. 30; p. 3: «it seems that many of the elements contained in the political thought of Dominican authors was conditioned by the influence of the structure of the quasi-democratic Order of which they were members»; p. 31: «Thus, within the Dominican Order there were definite features which may be described as democratic as well as a division of power between the various administrative bodies of the Order. These features distinguished the Dominican Order from the older religious orders».

25 B. A. Brill, The Situation of Dominican..., p. 30.

26 De Regia Potestate, I; Bleienstein, 75.

27 F. Bertelloni, «La crisis de la monarquía papal mediante um modelo causal ascendente: Juan de Paris, $D e$ Regia potestate et papali», Veritas 51, n.3 (Setembro, 2006), 51-66. One of Aristotle's lectiones of Política, 1281 a 40-43, allows stating that the multitude (plêthos) should have supremacy.

28 Cf. Pseudo-Dionysius' reductio ad unum in Coelesti Hierarchia and De Ecclesiastica Hierarchia.

29 Cf. Walter Ullmann, Il Pensiero Politico del Medioevo, Laterza, Roma-Bari, 1984, 227-261. 
Mendicant Orders' practice, ${ }^{30}$ where, as we said, a group of brothers elected their superiors, the entire people chose a single person from the group (a communitate) and placed him above the rest with the power to rule them. John Quidort mentions, in several contexts, the capability and the aptitude of the multitudo to choose and to elect his king. "To live well in common, they elect chiefs (rectores eligant) which vary according to the diversity of communities (diversos quidem secundum diversitatem communitatum)». ${ }^{31}$

Non est enim potestas nisi a Deo $(R m 13,1)$ : this is very clear. Not via the pope, but via «the people, consenting and electing (populo consentiente et elegente)», since «the people elected and continue to elect the king (a populo regem eligentem), by indicating a person or a family for the position (in persona uel in domo, sicut ante)». ${ }^{32}$ The King is King through people's will: «Rex est [rex] a populi voluntate». ${ }^{33}$ As we can see, the elective model is going its way.

But what is the transcendental condition of possibility of an elective model? It is the free will of men, definitely. «By natural right all possess the same freedom (de iure naturali est una omnium libertas)». ${ }^{34}$ As the aforementioned self-sufficiency, the libertas is also an essential determination of the perfecta multitudo. Yet, we have to say: freedom not only of the multitude as a whole, but of individuals as well, whether they will write or sign a text, without fear or constraint. The publication of the De Regia Potestate in 1302-1303, in the peak of the conflict between Philip the Fair $(l e \mathrm{Bel})$ and Boniface the $\mathrm{vIII}^{\text {th }}$, clearly against the plenitudo potestatis papalis, was the highest claim of freedom. Even more because he ends by telling us that «no one is permitted, under any circumstances, to write or teach against their conscience». (Nulli licitum est in casu quocumque contra conscientiam docere vel scribere in doctrina religionis). ${ }^{35}$ In the long journey of Western spirituality, this is an unmistakable declaration of the preeminence of inner life and of the primacy of consciousness.$^{36}$ Less than six months after, on June 26, 1303, he will be putting the first signature on top of a list of Saint Jacques' friars, appealing to a General Council in order to judge Boniface the vIII ${ }^{\text {th }}$. The Conciliarism of Marsilius of Padua, William of Ockham, Jean Gerson, etc., had just been born. We might say: the reform has begun long before the Reformation.

Fecha de recepción: día 27 de mayo de 2016

Fecha de aceptación: día 9 de septiembre de 2016

30 B. A. Brill, The Situation of Dominican..., p. 26: «The significance of the political activities and the scholastic productions of the members of the Dominican Order cannot be fully appreciated without some understanding of the institutional structure and educational organization within which they worked». Cf. Jean Leclerq, Jean de Paris et l'Écclesiologie du XIII e siècle, (Vrin, Paris, 1942), 126, n.5; Janet Coleman, «The Dominican Political Theory of John of Paris in its Context», in Diana Wood (ed.), The Church and Sovereignty c.590-1918: Essays in Honour of Michael Wilks (Basil Blackwell, Oxford, 1991), 187-223; In the De Regia Potestate, XIX; Bleienstein, 175, he declares that this type of elective model of government (eligentur plures ad omni provincia et de omni provincia) would also be the best government in the Church (esset optimum regimen eclesiae).

31 De Regia Potestate, III; Bleienstein, 82.

32 De Regia Potestate, X; Bleienstein, 113.

33 De Regia Potestate, XIX; Bleienstein, 172.173; Leclerq, 95, n.1.

34 De Regia Potestate, XIII; Bleienstein, 136 (cf. Decretum Magistri Gratiani, Distinctio prima, c. VII «Quid sit ius naturale»: «Ius naturale est commune omnium nationum (...), et omnium una libertas...»).

35 De Potestate Regia et Papali, XX. Bleienstein, 184, lineae 1-5.

36 We should remember the Luther's words, about two hundred years after (17 ${ }^{\text {th }}$ april 1521$)$ : «... mein Gewissen ist in den Worten Gottes gefangen. So kann und will ich nichts widerrufen, weil es gefährlich und verderblich ist, etwas gegen das Gewissen zu tun [capta est conscientia in verbis dei, revocare neque possum nec volo quicquam, cum contra conscientiam agree neque tutum neque integrum sit.] Ich kann nicht anderst, hie stehe ich. Gott helfe mir. Amen». 